\title{
The Impact of Chinese Trade and Investment on West African Economic Growth: A Spatial Econometrics Approach
}

\author{
Hua Wilfried Serge Koffi \\ School of Economics, Shanghai University, Shanghai, China \\ Email: khwilfried@yahoo.fr
}

How to cite this paper: Koffi, H.W.S. (2020) The Impact of Chinese Trade and Investment on West African Economic Growth: A Spatial Econometrics Approach. Open Journal of Applied Sciences, 10, 142-153.

https://doi.org/10.4236/ojapps.2020.104012

Received: March 20, 2020

Accepted: April 23, 2020

Published: April 26, 2020

Copyright () 2020 by author(s) and Scientific Research Publishing Inc. This work is licensed under the Creative Commons Attribution International License (CC BY 4.0).

http://creativecommons.org/licenses/by/4.0/

\section{(c) (i) Open Access}

\begin{abstract}
This paper has studied the West African region or Economic Community of West African States (ECOWAS) which includes fifteen countries and its relationship with China. Three countries (Côte d'Ivoire, Ghana, and Nigeria) of the fifteen countries which are economically representative in the west African region to represent the overall-region were studied. Therefore, the objective of this study is to investigate the spatial effect of Chinese trade and investment on the economic growth of West Africa. The study focuses on the period from 1960-2014 using the dynamic panel data approach and spatial autoregressive approach for the econometric analysis of this topic. Empirically, the results show that trade openness with China has a positive impact on the neighboring countries of the region, especially for those who share the same border. Chinese investment is vital to the region's economic growth as the results show that one dollar investment increase from China to the host country increases the economic growth in the neighboring countries by $0.328 \%$.
\end{abstract}

\section{Keywords}

China, Trade, Investment, West Africa, Economic Community of West African States (ECOWAS), Economic Growth

\section{Introduction}

Over the last decade, the relationship between China and Africa has been given a lot of attention by many scholars. China is trading and investing in all regions of Africa. In fact, Africa is divided into several economic regions which include the Economic Community of West Africa States (ECOWAS). ECOWAS is 
a 15 member regional group with a mandate of promoting economic integration in all fields of activity of the constituting countries.

The Member countries of ECOWAS are Benin, Burkina Faso, Cape Verde, Côte d'Ivoire, Gambia, Ghana, Guinea, Guinea Bissau, Liberia, Mali, Niger, Nigeria, Sierra Leone, Senegal and Togo.

Nigeria, Ghana and Côte d'Ivoire are the biggest exporters and importers of the ECOWAS region. Nigeria represents $73.5 \%$ of total ECOWAS exports, primarily as a result of its petroleum exports but also due to its broader economy. Nigeria is followed by Ghana and Côte d'Ivoire, which accounts for only $8 \%$ of total exports each. ECOWAS' agricultural exports are mainly led by Nigeria and Côte d'Ivoire, which account for $50 \%$ of the total agricultural commodity exports of the region. Côte d'Ivoire and Ghana are the main ECOWAS food exporters largely due to cocoa, followed by Nigeria.

In regards to imports, Nigeria absorbs $52 \%$ of total imports and $54 \%$ of agricultural imports. Nigeria is also by far the largest food importer in the region (51\% of total food imports). This is not surprising, given that Nigeria's GDP represents $65.2 \%$ of total ECOWAS GDP.

ECOWAS' main trading partners are highly industrialized countries such as China, India, the USA, the EU and Brazil, which buy raw materials from the region and sell back industrialized products (cars, ships, trucks, motorcycles, medicaments, etc.). The presence of China in West Africa became more and more important over the years. China is now the third largest trading partner of West Africa after the EU and India. The principal sectors of the trade relationship between West Africa and China are energy, agriculture (cocoa, rubber, and cotton), and other natural resources. China's focus on the West African region continent is not only for natural resources but also for investment (gross capital formation, human capital, capital stock) in order to encourage African states to build their economies.

In several studies, it has been verified that every region according to its correlation with other regions has a dynamic impact [1]. Due to economic interaction with each country or the spatial dependence of the region in the process of economic growth, it is important to do an econometric analysis of neighborhood effects. Therefore, the investment in the region benefits the host country but also has a positive effect on the neighboring countries. This proximity plays an important role in economic growth. Furthermore, trade with a partner outside the region, for instance, China contributes to the economic growth of the host country by leading them towards the improvement of their resources and their products. Therefore, in this paper, we will analyze the spatial effect of China's trade and investment on West Africa's economic growth. In other words, this paper will analyze the importance of spatial geographic proximity and the growth spillover effect of trade and investment in the neighboring countries.

The rest of this study will be structured as follows: the second section presents the literature review and the third one describes the methodology and data used 
in this study. In the fourth section, we describe and give the results of growth and trade openness with China on one hand, and on the other hand the findings of the analysis between investment and trade openness with China. Section five concludes this study.

\section{Literature Review}

International trade brings welfare and efficiency gains to all countries irrespective of their initial conditions, level of development, technological abilities and natural resources endowments. Foreign trade is recognized as a vital catalyst for economic development and has become more important to the West African economy in recent years. For West African countries, the contribution of trade to overall economic development is immense owing largely to the obvious fact that most of the essential elements for development such as capital goods, raw materials, and technical know-how, are mostly imported because of inadequate domestic supply. The export and import of goods and services have grown rapidly. Economic growth is measured by the Gross Domestic Product (GDP) in West Africa. By definition, GDP is a total market value of a country's output of goods and services, which are exchanged for money or traded in a market system over certain periods. This indicates that trade is an essential aspect of Economic growth. Africa and other parts of the developing world gained a lot of importance for economic and political reasons in the escalation of China's own globalization.

The active participation in the international market, by promoting trade, leads to more intense competition and improvement in terms of productivity [2]. They found that countries exporting a large share of their output seem to grow faster than others [3] [4]. Some Models suggest that expanded international trade increases the number of specialized inputs, increasing growth rates as economies become open to international trade [5]. The increase in trade (for whatever reason) produces more income (increase GDP), and more income facilitates more trade. The growth of trade has a stimulating influence across the economy as a whole in the form of technological spillovers and other externalities [6]. Therefore this open economy makes the country more interdependent on each other. This is supported by the fact that there are technological transfers, knowledge diffusions, labour migrations, institutional spillovers, contagious economic crises, the economies are interacting with each other [7]. In spatial terms, they are actually spatially dependent. In the last decade, changes in the structure of the global economy have led to greater dependence on economies and their impacts on each other. The neighbouring countries are benefiting and increasing productivity because when a country invests in and improves technology, the return on investment is greater than the domestic interest it owns.

Some studies also applied Solow's growth model with the technology spillover and Spatial Durbin Model (SDM) over the period of 1991-2007 [8]. They argued that there is a positive spatial dependency between different regions of China. 
Their paper revealed that the absolute convergence was rejected, but in contrast, the conditional convergence among the economic regions of China was accepted. Moreover, by discovering the club convergence that spatial interactions and regional economic growth have different behaviors.

Some empirical works use Spatial Durbin Model (SDM) in the Bayesian statistics framework to investigate the per capita income convergence in the regions of Japan in time period of 1989-2007 [9]. The empirical results revealed that by considering spatial dependency, Sigma $(\sigma)$ convergence and per capita income distribution reduction income have not occurred, but the occurrence of beta convergence was confirmed during the years of 1990-2007. Also, the same study was also done by authors who used spatial econometric models in panel data structure and stipulating fixed and dynamic weighted matrices. They have assessed the effects of economic growth spillover through trading and neighborhood between 26 countries which are members of the Organization of Economic Cooperation and Development (OECD) during the period 1970-2005 [10]. In this study, the spillover impacts through trading and the neighborhood were positively and significantly estimated, and the convergence rate of economic growth was upgraded after considering the spatial dependence. He also believes that trade is the starting point of the growth process.

\section{Methodology and Data}

Given the objectives of the study, the data used in this study are taken from the Penn World Table Open Access Database is a set of national-accounts data developed and maintained by scholars at the University of California, Davis and the Groningen Growth Development Centre of the University of Groningen to measure real GDP across countries and over time. This database provides a set of indicators on the economic development of countries around the world.

The data of this study cover a time horizon from 1960 to 2014, a 54-year period. There are also 3 individual units: Côte d'Ivoire, Ghana, and Nigeria. Thus, the data matrix corresponds to a long panel. The different variables used for modeling the relationship between economic growth, investment and foreign trade are presented in Table A1 (Annex 1).

For a better analysis of the dynamics of economic growth, we integrate the study of beta-convergence, which states that all countries converge towards a stable equilibrium in the long run. There is absolute convergence in which all countries converge towards a regular state independent of their endogenous characteristics. But we are in a context of conditional convergence where each country converges towards its static state resulting from its structural characteristics (savings rate, investment rate, level of technology, etc.).

Indeed, geographical proximity, membership of a common economic community (ECOWAS), the establishment of common economic and commercial agreements are all factors likely to impact the interactions between these different countries. The proposed convergence model of this study was inspired by 
previous studies and the seminal papers [11] [12]. It is described by the following equation:

$$
\ln \left(\frac{Y_{i t}}{Y_{i t-1}}\right)=\mu_{t, i}+\varepsilon_{t, i}
$$

$\ln \left(\frac{Y_{i t}}{Y_{i t-1}}\right)$ represents the growth rate and $\varepsilon_{t, i}$ is the error term.

$\mu_{t, i}$ is defined as follow:

$\mu_{t, i}=\alpha_{i}+\left(1-\mathrm{e}^{-v k}\right) \ln \left(Y_{i t-1}\right)$ where $v$ is convergence speed and $k$ is the convergence coefficient.

$$
\ln \left(\frac{Y_{i t}}{Y_{i t-1}}\right)=\alpha_{i}+\beta \ln \left(Y_{i t-1}\right)+\varphi \ln \left(X_{t, i}\right)+\varepsilon_{t, i}
$$

$\left\{\begin{array}{l}\text { If } \beta \text { is statically significant and negative then the convergence exists } \\ \text { If } \varphi \text { is statically different to } 0 \text { then the convergence is constant } \\ \text { If } \varphi \text { is not statically differentto } 0 \text { then the convergence is absolute }\end{array}\right.$

We (inspired by other authors) propose a rewrite of the previous equation in a dynamic form [13]:

$$
\begin{gathered}
\ln \left(y_{i t}\right)=\alpha_{i}+(1+\beta) \ln \left(y_{i t-1}\right)+\varphi \ln \left(X_{i t}\right)+\varepsilon_{i t} \\
\ln \left(y_{i t}\right)=\alpha_{i}+\omega \ln \left(y_{i t-1}\right)+\varphi \ln \left(X_{i t}\right)+\varepsilon_{i t} ; \omega=1+\beta
\end{gathered}
$$

The interactions between economic growth, investment and foreign trade with China can be affected by geographical proximity and linguistic concordance. Equation (4) takes into account geographic proximity and linguistic concordances. Spatial effects can be introduced in several ways. There are three (03) ways that are more commonly used: the model with staggered endogenous variable, the cross spatial model with staggered explanatory variables and the model with autocorrelation of errors [14]. Given the three ways of integrating spatial effects, Equation (4) modeling becomes:

$$
\ln \left(y_{i t}\right)=\alpha_{i}+\omega \ln \left(y_{i t-1}\right)+\gamma W \ln \left(X_{i t}\right)+\rho W \ln \left(y_{i t}\right)+\left(\zeta W \mu_{i t}+\vartheta_{i t}\right) ; \omega=1+\beta
$$

$X$ is the vector of the explanatory variables which can also include lagged values of $Y$.

$W$ is the weight matrix of Ghana, Côte d'Ivoire and Nigeria.

$$
\zeta \mu_{i t}+\vartheta_{i t}=\varepsilon_{i t}
$$

$\left\{\begin{array}{l}\text { if } \gamma=\zeta=0 \text { then the model becomes SAR(Spatial Auto Regressive Model) } \\ \text { if } \zeta=0 \text { and } \gamma \neq 0 \text { then the model becomes SDM(Spatial Durbin Model) }\end{array}\right.$

$\gamma$ and $\rho$ assess the influence of countries on the indicators of other countries. They therefore make it possible to capture the effects of growth shocks affecting other countries. For analyzing the convergence of different indicators in different countries, the modeling approach is based on panel data. This approach makes it possible to correct the omission and heterogeneity biases that would compromise the estimation coefficients if the data were cross-sectional 
[15]. The estimation approach and process are based on a set of assumptions about the similarity between countries. Indeed, if the countries have identical characteristics, we will make an estimation by the Ordinary Least Squares Method (OLS) while obviously considering the individual and temporal specificities if they exist. We will test as well the significance and performance of coefficients from the within regression. Otherwise, we will use dynamic panel modeling where estimation can be done using the GMM or instrumental variables approach.

The elements of the weight matrix $\mathrm{W}$ are written:

$$
\left\{\begin{array}{l}
W_{i j}=1 \text { if countries } i \text { and } j \text { have the same border } \\
W_{i j}=0 \text { if countries do not share the same border }
\end{array}\right.
$$

Thus, if we consider the 3-tuple (Ivory Coast, Nigeria, and Ghana), the matrix is written:

$$
W=\left(\begin{array}{lll}
0 & 0 & 1 \\
0 & 0 & 0 \\
1 & 0 & 0
\end{array}\right)
$$

This process of constructing the weight matrix is proposed by different authors [16] [17].

\section{Results and Discussions}

\subsection{Growth and Trade Openness with China}

According to Table 1, based on the SAC, the coefficients Economic growth rate $(t-1), \log$ Trade Openness squared $(t)$, Log Trade Openness $(t-1)$ and Log Households Spending to GDP $(t)$ were positive. Log Trade Openness $(t)$, Human Capital index $(t-1)$, Log Government spending to GDP $(t)$ are positive. The significance of these coefficients showed that the spatial correlation is based on the trade openness China. In addition, the spatial autocorrelation coefficient $\lambda$ indicates that the value of this coefficient is statistically significant and positive so the trade with China has an important in between the countries. This shows that a country with a year of economic growth has on average the potential to show even more growth the following year. Indirectly, spillover affects the economic growth of neighboring countries. If the average weighted economic growth of neighboring countries increases by $1 \%$, its economic growth will increase by $0.991 \%$.

Furthermore, the Hausman test shows that in the SAR and SDM models, the fixed effects were superior to the random effect model. Therefore the fixed effects model is more appropriate. When we take into account the spatial effect in the SAR model the convergence disappears but appears in the SDM Model. The $\mathrm{R}$-squared is for the SAR 0.2356, SDM 0.6436, SAC 0.0899. Therefore the SDM has the largest R-squared, which means that as a result selected it is more likely to be accepted as the most appropriated model. In our study, compared to other 
Table 1. Estimation of spatial regression of trade openness rate and economic growth rate.

\begin{tabular}{|c|c|c|c|c|c|}
\hline \multirow{2}{*}{ Model } & \multicolumn{2}{|c|}{ SAR } & \multicolumn{2}{|c|}{ SDM } & \multirow{2}{*}{$\begin{array}{c}\text { SAC } \\
\text { Pooled }\end{array}$} \\
\hline & Pooled & Within & Pooled & Within & \\
\hline \multicolumn{6}{|l|}{ Original Model } \\
\hline Economic growth rate $(t-1)$ & $0.187^{*}$ & $0.214^{* *}$ & 0.037 & 0.046 & 0.0390 \\
\hline Log Trade Openness $(t)$ & -0.056 & -0.0630 & $-0.126^{\star *}$ & $-0.168^{* * *}$ & $-0.128^{\star *}$ \\
\hline Log Trade Openness square $(t)$ & 0.004 & 0.0060 & 0.016 & $0.023^{*}$ & 0.017 \\
\hline Log Trade Openness $(t-1)$ & 0.031 & 0.0230 & 0.029 & 0.023 & 0.029 \\
\hline Human Capital Index $(t)$ & $0.611^{\star * *}$ & $0.616^{* * *}$ & $2.444^{* * *}$ & $2.39^{* * *}$ & $2.446^{\star * *}$ \\
\hline Human Capital index $(t-1)$ & $-0.605^{\star * *}$ & $-0.624^{* * *}$ & $-2.384^{* * *}$ & $-2.371^{\star * *}$ & $-2.386^{* * *}$ \\
\hline Log Government spending to GDP $(t)$ & -0.057 & -0.0090 & -0.013 & $-0.075^{*}$ & -0.016 \\
\hline Log Households Spending to GDP $(t)$ & -0.019 & -0.0110 & $0.093^{* * *}$ & $0.065^{\star * *}$ & $0.094^{* * *}$ \\
\hline Intercept & 0 & 0.1190 & & & \\
\hline \multicolumn{6}{|l|}{ Model with Spatial Effects } \\
\hline Economic growth rate $(t-1)$ & & & $0.164^{* *}$ & 0.000 & \\
\hline Log Trade Openness $(t)$ & & & $0.131^{*}$ & $0.152^{* *}$ & \\
\hline Log Trade Openness squared $(t)$ & & & -0.014 & $0.167^{\star * *}$ & \\
\hline Log Trade Openness $(t-1)$ & & & -0.031 & -0.021 & \\
\hline Human Capital Index $(t)$ & & & $-2.49^{* * *}$ & -0.025 & \\
\hline Human Capital index $(t-1)$ & & & $2.427^{\star * *}$ & $-2.442^{* * *}$ & \\
\hline Log Government spending to GDP $(t)$ & & & 0.03 & $2.417^{\star * *}$ & \\
\hline Log Households Spending to GDP $(t)$ & & & $-0.078^{\star *}$ & $0.079^{*}$ & \\
\hline \multicolumn{6}{|l|}{ Validation Indicators } \\
\hline \multicolumn{6}{|l|}{ Spatial Correlation } \\
\hline Rho $(\rho)$ & $-0.629^{\star * *}$ & $-0.596^{* * *}$ & $0.401^{\star * *}$ & $0.395^{\star * *}$ & -59505 \\
\hline Lambda $(\lambda)$ & & & & & $0.991^{* * *}$ \\
\hline \multicolumn{6}{|l|}{ Spatial Variance } \\
\hline lgt_theta $(\log \theta)$ & 0 & 0.9470 & & 14274 & 0.000 \\
\hline Sigma $(\sigma)$ squared_e & $0.009^{* * *}$ & $0.009^{* * *}$ & $0.001^{* * *}$ & $0.001^{* * *}$ & $0.001^{\star * *}$ \\
\hline$R$-squared & $27.15 \%$ & $23.56 \%$ & $22 \%$ & $64.36 \%$ & $8.99 \%$ \\
\hline Hausman Test & \multicolumn{2}{|c|}{-1.320} & \multicolumn{2}{|c|}{1.420} & 1 \\
\hline
\end{tabular}

${ }^{*}, * *$, and ${ }^{* * *}$ denote significance at $10 \%, 5 \%$, and $1 \%$ level.

models, the SDM explains better the impact of trade openness with china to economic growth. In other words, it explains better the spatial correlation coefficient between the error and the spatial correlation.

The trade openness coefficient with China is significant and positive. According to the aforementioned matrix, these results mean that the Chinese trade with Ghana has a positive impact on the economic growth of Côte d'Ivoire. Also, the 
trade between China and Côte d'Ivoire has a positive impact on the economic growth of Ghana. This proximity creates growth spillover through foreign trade in the West African region.

\subsection{Investment and Trade Openness}

According to Table 2 below, based on the SAC, the coefficients Investment Computation Index $(t-1)$, Log Trade Openness squared $(t)$, Log Trade openness squared $(t-1)$, Log Government spending to GDP $(t)$ and Log Households Spending to GDP $(t)$ were positive. In this analysis, only the Log Trade Openness squared $(t-1)$ was negative. Based on the SAC model, investment from the previous period has a positive impact on economic growth. That means, an

Table 2. Estimation of spatial regression of investment and economic growth rate.

\begin{tabular}{|c|c|c|c|c|c|}
\hline \multirow{2}{*}{ Model } & \multicolumn{2}{|c|}{ SAR } & \multicolumn{2}{|c|}{ SDM } & \multirow{2}{*}{$\begin{array}{c}\text { SAC } \\
\text { Pooled }\end{array}$} \\
\hline & Pooled & Within & Pooled & Within & \\
\hline \multicolumn{6}{|l|}{ Original Model } \\
\hline Investment Computation index $(t-1)$ & $0.398^{* * *}$ & $0.427^{\star}$ & 0.064 & 0.065 & $0.388^{* * *}$ \\
\hline Log Trade openness $(t)$ & $0.002^{\star}$ & 0.002 & $0.008^{* * *}$ & $0.008^{\star * *}$ & $0.002^{*}$ \\
\hline Log Trade openness squared $(t)$ & -0.0001 & -0.0001 & $-0.001^{\star *}$ & $-0.001^{\star \star}$ & -0.0001 \\
\hline Log Trade openness squared $(t-1)$ & 0.0002 & 0.0002 & 0.001 & 0.001 & 0.0002 \\
\hline Log Government spending to GDP $(t)$ & 0.001 & 0.001 & -0.001 & -0.001 & 0.0010 \\
\hline Log Households Spending to GDP $(t)$ & $0.001^{\star * *}$ & $0.001^{\star *}$ & $0.002^{*}$ & $0.002^{\star}$ & $0.001^{* * *}$ \\
\hline Intercept & & & & 0.001 & \\
\hline \multicolumn{6}{|l|}{ Model with Spatial Effects } \\
\hline Investment Computation Indicator $(t-1)$ & & & $0.313^{* * *}$ & $0.328^{* * *}$ & \\
\hline Log Trade Openness $(t)$ & & & $-0.006^{* *}$ & $-0.007^{* * *}$ & \\
\hline Log Trade Openness squared $(t)$ & & & 0.001 & $0.001^{\star *}$ & \\
\hline Log Trade Openness $(t-1)$ & & & -0.002 & -0.002 & \\
\hline Human Capital Index $(t)$ & & & 0.003 & 0.002 & \\
\hline Human Capital index $(t-1)$ & & & -0.001 & $-0.002^{\star}$ & \\
\hline \multicolumn{6}{|l|}{ Validation Indicators } \\
\hline \multicolumn{6}{|l|}{ Spatial Correlation } \\
\hline Rho $(\rho)$ & $0.491^{\star * *}$ & $0.449^{* * *}$ & $0.562^{* * *}$ & $0.568^{\star * *}$ & $0.506^{* * *}$ \\
\hline Lambda $(\lambda)$ & & & & & -0.056 \\
\hline \multicolumn{6}{|l|}{ Spatial Variance } \\
\hline lgt_theta $(\log \theta)$ & & $-2.08^{\star * *}$ & 31258 & & \\
\hline Sigma $(\sigma)$ squared_e & $3.91 \mathrm{E}-06$ & $3.91 \mathrm{E}-06^{* * *}$ & $2.66 \mathrm{E}-06^{\star * *}$ & $2.7 \mathrm{E}-06^{\star * *}$ & 4.10 \\
\hline$R$-squared & $78.33 \%$ & $80.07 \%$ & 0.84 & $88.27 \%$ & $77.78 \%$ \\
\hline Hausman Test & \multicolumn{2}{|c|}{-1.050} & \multicolumn{2}{|c|}{0.010} & 1 \\
\hline
\end{tabular}

${ }^{*},{ }^{*}$, and ${ }^{* * *}$ denote significance at $10 \%, 5 \%$, and $1 \%$ level. 
increase of one dollar investment will increase the economic growth between the countries by $0.388 \%$. With an increase of one percent of the trade openness rate, the economic growth rate of neighboring countries will increase by $0.002 \%$. Also, the Log Households Spending to GDP $(t)$ is significant and has a positive impact on economic growth in the region.

In addition, the stability of $\rho$ indicates whether the average weighted economic growth of neighboring countries increases by $1 \%$, economic growth will increase by $0.506 \%$ and $\lambda$ will not be significant.

The Hausman test showed that in the SAR and SDM models, the fixed effects were superior to the random effect model. Therefore the fixed effects model is more appropriate. When we take into account the spatial effect in the SAR model the convergence disappears but appears in the SDM Model. The R-squared is for the SAR 0.8007, SDM 0.8827, SAC 0.7778. Therefore the SDM has the largest $\mathrm{R}$-squared, which means that as a result selected it is more likely to be accepted as the most appropriated model. In our study, compared to other models, the SDM explains better the impact of investment from China to economic growth. In other words, it explains better the spatial correlation coefficient between the error and the spatial correlation. The investment coefficient from China is significant and positive. A one dollar investment increase from China to the host country will increase the economic growth in the neighboring countries by $0.328 \%$. Also, the coefficient of the Human Capital index $(t-1)$ Log Trade Openness $(t)$ is significant but negative. The significance of these coefficients means the spatial correlation in the performance relation is based on investments. This proximity creates growth spillover through foreign investment in the West African region.

\section{Summary and Conclusion}

A spatial regression approach helped us to better understand the impact of Chinese trade and investment with a host country inside the West African region on its neighboring countries economic growth. This proximity and spatial interaction between the countries' in the West African region plays an important role on the economic growth of this economic zone and on the individual performance of the countries.

The two tables above show that trade and investment are a significant determinant of economic growth, especially when this is spatially modeled, trade and investment generate a positive spillover in the neighboring countries. The exploratory spatial data analysis detects strong spatial dependence and clusters of high per capita income in West Africa region.

The trade openness with China has a positive impact on the neighboring countries of the region, especially for those whom share the same border. This is demonstrated by the significant positive coefficient of the spatial autocorrelation. The table also showed that the coefficient of economic growth of the previous and log trade openness was positively significant, which means continuing 
trading with china has a positive spillover effect of growth of one country to its neighboring countries. If the average weighted economic growth of neighboring countries increases by $1 \%$, its economic growth will increase by $0.991 \%$.

Regarding the investment and the openness of West African countries to China, some results were positive and some were negative. The investment of the previous year was significantly positive. That means if, for example, a country decides to invest in technology in order to absorb the Chinese inflows, this will increase its return on investment, productivity and the neighboring countries will benefit from this improvement. As openness with China increases, the capital flow will also increase. The results showed that one dollar investment increase from China to the host country will increase the economic growth in the neighboring countries by $0.328 \%$.

In addition, the human capital of the previous period is negatively significant, which means there is no global effort and good investment in people. Thus, this has a negative impact on economic growth because the lack of education doesn't contribute to the economy of the region.

Finally, the results in Table 2 showed that Stability of $\rho$ indicates whether the average weighted economic growth of neighboring countries increases by $1 \%$, economic growth will increase by $0.506 \%$. Thus the spatial correlation in the performance relation is based on investments and this proximity creates growth spillover through foreign investment in the West African region.

Finally, this study is limited by the fact that many West African countries are low income countries and it was really difficult to get all the data, measure the variables, get in contact with their authorities in order to have accurate information. Therefore we largely omitted from this study, development aid, minerals and oils sectors data, diplomatic missions, legislative influence as variables.

\section{Conflicts of Interest}

The author declares no conflicts of interest regarding the publication of this paper.

\section{References}

[1] MoradSeif, A., Panahi, H. and Razi, D.H. (2017) Regional Economic Growth and Spatial Spillover Effects in MENA Area. Iranian Economic Review, 21, 765-787.

[2] Mankiw, N.G., Romer, D. and David, W. (1992) A Contribution to the Empirics of Economic Growth. Quarterly Journal of Economics, 107, 407-437. https://doi.org/10.2307/2118477

[3] Michaely, M. (1977) Exports and Growth: An Empirical Investigation. Journal of Development Economics, 4, 49-53. https://doi.org/10.1016/0304-3878(77)90006-2

[4] Feder, G. (1982) On Exports and Economic Growth. Journal of Development Economics, 12, 59-73. https://doi.org/10.1016/0304-3878(83)90031-7

[5] Romer, P.M. (1986) Increasing Returns and Long-Run Growth. The Journal of Political Economy, 94, 1002-1037. https://doi.org/10.1086/261420

[6] Bhagwati, J.N. (1988) Export-Promoting Trade Strategy: Issues and Evidence. World Bank Research Observer, 3, 27-57. https://doi.org/10.1093/wbro/3.1.27 
[7] Anselin, L. (1988) Spatial Econometrics: Methods and Models. Kluwer Academic, Dordrecht. https://doi.org/10.1007/978-94-015-7799-1

[8] Tian, L., Wang, H.H. and Chen, Y. (2010) Spatial Externalities in China Regional Economic Growth. China Economic Review, 21, S20-S31. https://doi.org/10.1016/j.chieco.2010.05.006

[9] Seya, H., Tsutsumi, M. and Yamagata, Y. (2012) Income Convergence in Japan: A Bayesian Spatial Durbin Model Approach. Economic Modelling, 29, 60-71. https://doi.org/10.1016/j.econmod.2010.10.022

[10] Yu Ho, C., Wang, W. and Yu, J. (2013) Growth Spillover through Trade: A Spatial Dynamic Panel Data Approach. Economics Letters, 120, 450-453. https://doi.org/10.1016/j.econlet.2013.05.027

[11] LeSage, J.P. and Fischer, M. (2008) Spatial Growth Regressions: Model Specification, Estimation and Interpretation. Spatial Economic Analysis, 3, 275-304. https://doi.org/10.1080/17421770802353758

[12] Barro, R.J. and Sala-i-Martin, X. (1992) Convergence. Journal of Political Economy, 100, 223-225. https://doi.org/10.1086/261816

[13] Caselli, F., Esquivel, G. and Lefort, F. (1996) Reopening the Convergence Debate: A New Look at Cross-Country Growth Empirics. Journal of Economic Growth, 1, 363-389. https://doi.org/10.1007/BF00141044

[14] Baltagi, B. (2001) Econometric Analysis of Panel Data. 2nd Edition, John Wiley and Sons, Chichester.

[15] Islam, N. (2003) What Have We Learnt from the Convergence Debate? Journal of Economic Surveys, 17, 309-362. https://doi.org/10.1111/1467-6419.00197

[16] Luc, A., Le Gallo, J. and Jayet, H. (2008) Spatial Panel Econometrics. In: The Econometrics of Panel Data: Fundamentals and Recent Developments in Theory and Practice, Part of the Advanced Studies in Theoretical and Applied Econometrics Book Series (ASTA, Volume 46), Springer, Berlin, 625-660. https://doi.org/10.1007/978-3-540-75892-1_19

[17] Salima, B.A. and Vedrine, L. (2011) Fostering the Development of European Regions: A Spatial Dynamic Panel Data Analysis of the Impact of Cohesion Policy. Regional Studies, 47, 1-21. https://doi.org/10.1080/00343404.2011.628930 


\section{Annexe 1}

Table A1. Variables of the study.

\begin{tabular}{cccc}
\hline Variable Label & Unit & Variable name & Nature \\
GDP & PPP & cgdpo & Exogenous \& Endogenous \\
Square GDP & PPP & cgdpo2 & Exogenous \\
Cube GDP & PPP & cgdpo3 & Exogenous \\
Volume of African exports to China & PPP & csh_x & Exogenous \& Endogenous \\
Volume of African imports from China & PPP & csh_m & Exogenous \& Endogenous \\
Gross capital formation & PPP & csh_i & Exogenous \& Endogenous \\
Population growth rate & $\%$ & G & Control Variable \\
Human capital index & PPP & Hc & Exogenous \& Endogenous \\
Household consumption expenditure & PPP & csh_c_c & Exogenous \& Control variable \\
Government consumption expenditure & PPP & csh_g & Exogenous \& Control variable \\
\hline
\end{tabular}

Source: Penn World Table, version 9.0. 